\title{
Chicory for milk production
}

\author{
C.D. WAUGH, D.A.CLARK, S.L. HARRIS, E.R. THOM, P.J.A. COPEMAN and A.R. NAPPER \\ Dairying Research Corporation, Private Bag 3123, Hamilton, New Zealand
}

\begin{abstract}
The 1997-98 season has seen a marked increase in the amount of chicory planted on dairy farms in New Zealand. However, no New Zealand data are available for milk production from dairy cows grazing chicory. As part of a larger trial examining the effect of summer forage crops on milk production, Grasslands Puna chicory was compared with Barkant turnips. In January and March 1998, grazing trials were conducted at No.1 Dairy, Dairying Research Corporation using 60 lactating twin cows. In January, chicory and turnips were break-fed at a constant allowance $(4 \mathrm{~kg} \mathrm{DM} / \mathrm{cow} /$ day) to supplement pasture offered at 3 allowances $(15,27.5$ and $40 \mathrm{~kg} \mathrm{DM} / \mathrm{cow} /$ day). In March, these crops were fed at 3 levels $(0,4$ and $8 \mathrm{~kg} \mathrm{DM} /$ cow/ day) to supplement pasture offered at a constant allowance of $25 \mathrm{~kg} \mathrm{DM} / \mathrm{cow} /$ day. Chicory and turnips gave similar milksolids (MS) responses of 40-41 g MS/kg DM offered in January. Milksolids responses in March were higher for turnips, $34 \mathrm{~g}$ $\mathrm{MS} / \mathrm{kg}$ DM vs $32 \mathrm{~g}$ MS/kg DM from chicory. In January and March the size of the milksolids response declined with increasing allowance. This could be attributed to an increasing amount of substitution at higher allowances. Chicory produced between 8.8 and $13.8 \mathrm{t} \mathrm{DM} /$ ha from 4 October to 10 March, offering a high quality summer-autumn forage crop and improved milk production when supplemented with pasture.
\end{abstract}

Keywords: chicory, Cichorium intybus, pasture allowance, dairy cows, milk production, forage crops, turnips, milksolids

\section{Introduction}

Chicory (Cichorium intybus) is a perennial herb with the potential to produce large quantities of highquality summer feed. Pure chicory swards in the Manawatu yielded $9 \mathrm{t} \mathrm{DM/ha} \mathrm{from} \mathrm{mid-November} \mathrm{to}$ May (Li et al. 1997) and mixed grass-chicory swards were persistent under rotational grazing (Lancashire $\&$ Brock 1983). A forage crop such as chicory could provide extra summer and autumn feed to supplement pasture.
Grasslands Puna chicory was released in 1985 as the world's first forage cultivar of chicory (Rumball 1986). Around 1993, about 10000 ha of Puna chicory was being sown annually in New Zealand (Moloney \& Milne 1993). Animal production data are available for sheep, beef cattle and deer grazing chicory. The 199798 season has seen a marked increase in the amount of chicory planted on dairy farms, both as a component of ryegrass-white clover pastures and as a specialist crop (Bodeker, pers. comm. 1998). However, no New Zealand data are available for milk production from dairy cows grazing chicory.

Earlier experiments showed that supplementing 25 $\mathrm{kg} \mathrm{DM} /$ cow/day pasture with $4 \mathrm{~kg} \mathrm{DM} /$ cow/day turnips increased milksolids (MS) production by $24 \%$ in summer and $28 \%$ in autumn (Clark et al. 1997). Offering $8 \mathrm{~kg}$ DM turnips/cow/day instead of $4 \mathrm{~kg} \mathrm{DM} /$ cow/day did not increase MS yield. In this experiment, Puna chicory was compared with Barkant turnips as a summer-autumn forage crop for milk production from dairy cows. Data presented are from grazing trials conducted in January and March 1998 at No. 1 Dairy of the Dairying Research Corporation in Hamilton. In January (Periods A and B) the aim was to test for any interaction between pasture and crop allowance affecting the size of the MS response. In March (Periods C and D), MS responses to different allowances of chicory and turnips were determined.

\section{Materials and methods}

\section{Trial design}

The trial design was a $2 \times 3$ factorial crossover where cows crossed over to a different allowance between experimental periods A and B in January and periods C and $\mathrm{D}$ in March. A 1-week uniformity period, where all cows grazed together, preceded January and March periods. Each herd then grazed treatments for two 8-day periods. During the second 8-day measurement period, cows remained on the same crop, but were allocated to one of the two feeding levels not previously offered to those cows. In January, Puna chicory and Barkant turnips (one twin cow on each crop) were breakfed at a constant allowance (4 $\mathrm{kg} \mathrm{DM} / \mathrm{cow} /$ day) to supplement pasture offered at 3 allowances $(15,27.5$ and $40 \mathrm{~kg} \mathrm{DM} / \mathrm{cow} /$ day). In March, these crops were fed at 3 levels $(0,4$ and $8 \mathrm{~kg} \mathrm{DM} / \mathrm{cow} /$ day) to supplement pasture offered at a constant allowance of $25 \mathrm{~kg} \mathrm{DM} / \mathrm{cow} /$ day. 


\section{Animals}

In each experimental period, 60 lactating, monozygous twin dairy cows, balanced for current MS yield, age, breed, liveweight and stage of lactation were allocated to 6 treatment herds. Milk production and composition data from the 1-week uniformity period were used as a covariate.

\section{Site and management}

Pasture: Experimental herds grazed existing perennial ryegrass-based pasture.

Chicory: Two 1 ha paddocks were sprayed with $1.4 \mathrm{~kg}$ ai/ha glyphosate (equivalent to $41 /$ ha Roundup ${ }^{\circledR}$ ) plus 0.251 Pulse surfactant on 23 August and 10 September 1997 respectively. Following spraying, in midSeptember, $700 \mathrm{~kg}$ 'Pasture 6' fertiliser/ha (6:6:6:14) was applied during cultivation. Two days before sowing trifluralin (Treflan) herbicide was soil-incorporated at $1.2 \mathrm{~kg} / \mathrm{ha}$. Puna chicory was sown at $6 \mathrm{~kg} / \mathrm{ha}$ on 4 October. On 15 November the seedlings were sprayed with $2 \mathrm{~kg} / \mathrm{ha}$ haloxyfop (Gallant) $+0.07 \mathrm{~kg} / \mathrm{ha}$ flumetsulam (Preside) and 0.51 Uptake crop oil to control weeds. Urea was applied post-grazing at $37 \mathrm{~kg} \mathrm{~N} / \mathrm{ha}$ as a split dressing (in mid-December and late December/ early January). Near the end of the March trial period, caterpillars (white butterfly, diamond-backed moth, cutworm) caused severe damage to the crop. After grazing, the chicory was sprayed with $0.57 \mathrm{~kg} / \mathrm{ha}$ chlorpyrifos (Lorsban 40 EC) insecticide.

Turnips: Two 1 ha paddocks were sprayed out with 1.4 $\mathrm{kg}$ ai/ha glyphosate plus 0.251 Pulse surfactant before cultivation. During cultivation, $500 \mathrm{~kg} / \mathrm{ha}$ borated superphosphate was soil incorporated. Superstrike Barkant turnips were sown at $2 \mathrm{~kg}$ coated seed/ha, on 26 October (1 ha) and 1 December 1997 (1 ha) respectively. Urea was applied at $55 \mathrm{~kg} \mathrm{~N} /$ ha 4 weeks after sowing to the October sown crop and 2 weeks after sowing to the December sown crop. Application of 0.1 $\mathrm{kg} /$ ha haloxyfop (Gallant) $+0.43 \mathrm{~kg} /$ ha picloram +0.64 $\mathrm{kg} /$ ha clopyralid (Radiate) herbicide and $1 \mathrm{l} /$ ha and 0.51 Uptake crop oil was carried out post-emergence to control grasses and broadleaf weeds such as black nightshade (on 4 December 1997 for the early-sown crop and 27 December for the late sown crop). The latesown crop also had a protectant fungicide, $0.8 \mathrm{~kg} / \mathrm{ha}$ mancozeb (Mancozeb 80W) applied on 31 December to control downy mildew.

\section{Measurements}

Pasture and crop: Pasture and crop allowances were based on pre-grazing herbage yield from quadrat cuts. Pasture yield was estimated from six $0.2 \mathrm{~m}^{2}$ quadrats cut to ground level. Chicory yield was measured by sampling eight $0.2 \mathrm{~m}^{2}$ quadrats cut to near ground level (just above the crown) and turnip yield from eight $1 \mathrm{~m}^{2}$ quadrats. Samples of pasture and crop were taken for chemical composition, dry matter percent (DM\%) and leaf:bulb ratios of turnips.

Herbage nitrate levels were tested before each experimental period to ensure the crops were non-toxic. Pasture and crop quality (acid detergent fibre (ADF), neutral detergent fibre (NDF), metabolisable energy content (MJ ME/kg DM), in vitro organic matter digestibility (IVD), crude protein (CP), soluble carbohydrate (sol CHO)) were determined by near infrared spectroscopy (NIRS).

Milk yield and composition: Individual cow milk yield was recorded daily for the entire trial and milk composition (fat, protein, lactose content) was measured once during each uniformity week and over the final four days of each measurement period.

\section{Statistical analysis}

The data were analysed using the SAS statistical package (version 6.12) mixed models procedure. Uniformity data were used as a covariate and random effects were specified for cows and twins. Analysis included a test for carryover effects from period $\mathrm{A}$ to $\mathrm{B}$ and period $\mathrm{C}$ to $\mathrm{D}$ when cows were offered a different allowance. Means were adjusted for carryover when this was significant (milk yield and protein $\%$ in all periods; fat $\%$ only in periods $\mathrm{C}$ and $\mathrm{D}$ ).

\section{Results}

\section{Climate}

The rainfall from October 1997 to April 1998 inclusive was $22.5 \%$ below the 10 -year average with average monthly rainfall of $67.7 \mathrm{~mm}$ compared with $84.4 \mathrm{~mm}$. Over 16 days from 27 December 1997 to 21 February 1998 there was only $37 \mathrm{~mm}$ rain, with screen maximum air temperatures above $25^{\circ} \mathrm{C}$ on 26 of these 57 days. Rainfall in January was only $21.6 \mathrm{~mm}, 78 \%$ below the 10-year average.

\section{Crop yields}

The early-sown turnip crop yielded $8.2 \mathrm{t} \mathrm{DM} /$ ha and was grazed during January, 72 to 88 days after sowing. The late-sown crop yielded $8.7 \mathrm{t} \mathrm{DM} /$ ha and was grazed during March, 94 to 110 days after sowing. Accumulated chicory yield from 4 October 1997 to 27 April 1998 in the two paddocks sown was $8.8 \mathrm{t} \mathrm{DM} /$ ha and $16.3 \mathrm{t}$ $\mathrm{DM} /$ ha. The higher-yielding paddock was grazed during the experimental periods. Chicory yield in this paddock from 4 October to 10 March was estimated at $13.8 \mathrm{t}$ 
$\mathrm{DM} / \mathrm{ha}$, growth rates reaching $194 \mathrm{~kg} \mathrm{DM} /$ ha/day in early January.

\section{Feed quality}

Chicory had a lower DM content than turnips in both periods (Table 1). In both periods the turnips fed were leafy with small bulbs. Crop and pasture DM\% were lower in March.

Table 1 Mean DM\% of chicory and turnips, mean leaf and bulb $\mathrm{DM} \%$ and leaf:bulb ratio of turnips in January and March 1998.

\begin{tabular}{lcrrrr}
\hline & $\begin{array}{c}\text { Chicory } \\
\text { Leaf }\end{array}$ & Whole & Leaf & Bulb & $\begin{array}{c}\text { Leaf:Bulb } \\
\text { ratio (fresh) }\end{array}$ \\
\hline January & 8.6 & 10.6 & 11.5 & 9.7 & 1.43 \\
March & 7.5 & 9.0 & 9.1 & 8.8 & 1.38 \\
\hline
\end{tabular}

In January and March 1998 chicory and turnips both had lower NDF and ADF than the pasture. Chicory had higher IVD and ME than either turnips or pasture. Crude protein levels in chicory were consistently high in January $(22.5 \%)$ and March $(22.9 \%)$ and similar to pasture. Turnip crude protein levels were lower $(12.9 \%$ and $16.0 \%$ in January and March respectively) than the chicory or pasture. Some data were not obtainable from the NIRS results owing to lack of sufficient data for calibration of NIRS predictions.

Pasture in the March trial (after a summer drought) was of poorer quality than in January. The energy value of the March pasture was averaged only 9.7 MJ ME/kg DM compared with 11.9 MJ ME/kg DM for the January trial.

\section{Milk yield and composition}

Milk volume and MS yield were significantly increased both with increasing allowance of pasture supplemented by a constant crop allowance (January) (Table 2) and with increasing allowance of crop to supplement a constant pasture allowance (March) (Table 4).

In January, cows grazing the turnips produced significantly more milk (15.0 $\mathrm{l} / \mathrm{cow} / \mathrm{day})$ than those grazing chicory $(14.61 / \mathrm{cow} /$ day $)$ regardless of pasture allowance $(\mathrm{P}<0.001)$. MS responses declined with increasing pasture allowance from $56 \mathrm{~g} \mathrm{MS} / \mathrm{kg} \mathrm{DM}$ offered at the $15 \mathrm{~kg} \mathrm{DM} / \mathrm{cow} /$ day pasture allowance to $28 \mathrm{~g} \mathrm{MS} / \mathrm{kg} \mathrm{DM}$ at the $40 \mathrm{~kg} \mathrm{DM} / \mathrm{cow} /$ day allowance, following a quadratic relationship $(\mathrm{P}<0.001)$.

In March, cows grazing the turnips again produced significantly more milk (11.3 l/cow/day) than those grazing chicory $(10.8 \mathrm{l} / \mathrm{cow} / \mathrm{day})$ regardless of treatment $(\mathrm{P}<0.001)$. MS production from cows grazing turnips was significantly higher than those grazing chicory. Milk fat content was higher for cows grazing chicory

Table 2 Mean DM\% and chemical composition* of whole turnip, chicory leaf and pasture determined by NIRS in January and March 1998.

\begin{tabular}{|c|c|c|c|c|c|c|c|}
\hline & DM & NDF & ADF & IVD & $\mathrm{CP}$ & sol CHO & $\begin{array}{c}\mathrm{ME} \\
(\mathrm{MJ} \mathrm{ME} / \mathrm{kg} \mathrm{DM})\end{array}$ \\
\hline \multicolumn{8}{|l|}{ January } \\
\hline Turnips & 10.6 & 25.8 & 19.4 & 76.8 & 12.9 & 26.9 & 12.1 \\
\hline Chicory & 8.6 & 25.5 & 19.7 & 83.4 & 22.5 & 11.6 & 12.8 \\
\hline Pasture & 26.3 & 41.0 & 30.2 & 76.2 & 20.0 & 9.8 & 11.9 \\
\hline \multicolumn{8}{|l|}{ March } \\
\hline Turnips & 9.0 & 21.1 & 21.1 & - & 16.0 & 18.2 & - \\
\hline Chicory & 7.5 & 19.8 & 18.9 & 76.4 & 22.9 & 9.6 & 11.4 \\
\hline Pasture & 22.8 & 48.5 & 25.8 & 64.9 & 24.3 & 6.7 & 9.7 \\
\hline
\end{tabular}

* neutral detergent fibre (NDF), acid detergent fibre (ADF), in vitro organic matter digestibility (IVD), crude protein (CP), soluble carbohydrate (sol CHO), metabolisable energy content (MJ ME/kg DM)

Table 3 Milk production (I/cow/day), composition (\%) and milksolids yield (kg MS/cow/day) and responses (kg MS/kg DM offered) from turnips and chicory fed at 3 levels of pasture allowance with a constant crop allowance of $4 \mathrm{~kg} \mathrm{DM} /$ cow/day in January 1998.

\begin{tabular}{|c|c|c|c|c|c|c|c|}
\hline & \multicolumn{4}{|c|}{-------- Pasture allowance (kg DM/cow/day) -------- } & \multicolumn{2}{|c|}{---------- Crop ---------- } & \multirow[b]{2}{*}{ SED } \\
\hline & 15 & 27.5 & 40 & SED & Chicory & Turnips & \\
\hline Milk production & 13.7 & 15.1 & 15.6 & $0.144^{* * *}$ & 14.6 & 15.0 & $0.119^{* * *}$ \\
\hline Fat $\%$ & 4.48 & 4.43 & 4.47 & $0.038 \mathrm{NS}$ & 4.51 & 4.41 & $0.038^{*}$ \\
\hline Protein $\%$ & 3.21 & 3.32 & 3.33 & $0.017^{\star * *}$ & 3.29 & 3.29 & $0.017 \mathrm{NS}$ \\
\hline Milksolids yield & 1.06 & 1.19 & 1.24 & $0.017^{* * *}$ & 1.16 & 1.17 & $0.012 \mathrm{NS}$ \\
\hline Milksolids response & 0.056 & 0.037 & 0.028 & $0.0009^{* * *}$ & 0.040 & 0.041 & $0.0007 \mathrm{NS}$ \\
\hline
\end{tabular}

NS = not significant; ${ }^{*} \mathrm{P}<0.05 ;{ }^{* *} \mathrm{P}<0.01 ;{ }^{* *} \mathrm{P}<0.001$ 
Table 4 Milk production (I/cow/day), composition (\%) and milksolids yield (kg MS/cow/day) and responses (kg MS/kg DM offered) from turnips and chicory fed at 0,4 and $8 \mathrm{~kg} \mathrm{DM} / \mathrm{cow} /$ day with a constant pasture allowance of $25 \mathrm{~kg} \mathrm{DM} / \mathrm{cow} /$ day in March 1998.

\begin{tabular}{|c|c|c|c|c|c|c|c|}
\hline & \multicolumn{4}{|c|}{------------- Crop allowance (kg DM/cow/day) } & \multicolumn{2}{|c|}{----------- Crop ----------- } & \multirow[b]{2}{*}{ SED } \\
\hline & 0 & 4 & 8 & SED & Chicory & Turnips & \\
\hline Milk production & 10.38 & 10.97 & 11.70 & $0.177^{* * *}$ & 10.75 & 11.28 & $0.145^{* * *}$ \\
\hline Protein \% & 3.49 & 3.50 & 3.55 & $0.023^{*}$ & 3.53 & 3.50 & $0.020 \mathrm{NS}$ \\
\hline Milksolids yield & 0.87 & 0.98 & 1.04 & $0.016^{* * *}$ & 0.930 & 0.990 & $0.013^{* * *}$ \\
\hline Milksolids response & 0.035 & 0.034 & 0.031 & $0.0004^{* * *}$ & 0.032 & 0.034 & $0.0005^{\star * *}$ \\
\hline
\end{tabular}

NS = not significant; ${ }^{*} \mathrm{P}<0.05 ;{ }^{* *} \mathrm{P}<0.01 ;{ }^{* * *} \mathrm{P}<0.001$

than turnips, $4.51 \%$ vs $4.41 \%$ in January $(\mathrm{P}<0.05)$ and $4.97 \%$ vs $4.85 \%$ in March $(\mathrm{P}<0.001)$. Milk protein content, however, was not significantly different in either experimental period $(3.3 \%$ in January and $3.5 \%$ in March) irrespective of crop.

MS responses from chicory in January were not significantly different from those of turnips (40-41 g MS/kg DM offered). In March, the MS response was significantly higher from turnips, $34 \mathrm{~g} \mathrm{MS} / \mathrm{kg} \mathrm{DM}$ compared with $32 \mathrm{~g} \mathrm{MS} / \mathrm{kg} \mathrm{DM}(\mathrm{P}<0.0005)$. There was no interaction between crop type and allowance. The same trends in milk production were evident for milk production from chicory and turnips.

\section{Discussion}

Results from the January trial show cows grazing turnips produced more milk than those grazing chicory at the same allowance. Milk production responses were similar from turnips and chicory at the same pasture allowance (Table 3), indicating the potential of chicory as a useful summer forage crop for dairy production. There was no interaction between pasture allowance and crop type.

In January CP levels in turnips were below the 16$18 \%$ recommended for lactating dairy cows (NRC 1989). NRC recommendations advise a minimum of $15 \% \mathrm{CP}$ in the diet to maintain milk production in lactating cows producing $15 \mathrm{l} / \mathrm{cow} /$ day. The CP levels of chicory were similar to those of the pasture, and at $23 \%$ indicative of a high quality feed. In March, CP levels of the turnips were adequate $(16 \%)$, though still below the chicory and pasture levels.

Soluble carbohydrate levels for pasture in both periods and chicory in March were below the 10\% recommended level for adequate rumen activity $(9.8$ and $6.7 \%$ for pasture and 12.6 and $9.6 \%$ for chicory in January and March respectively). These low soluble carbohydrate levels for pasture and chicory may have reduced rumen microbial fermentation and hence digestion. The combination of this with low NDF and ADF levels for chicory in March could help explain the lower milk yield from cows grazing the chicory compared with the turnips.
Both chicory and turnips increased milk production when offered as a supplement to pasture. In January, the MS responses from chicory were not significantly different from turnips, however in March, the MS response was significantly higher from turnips $(\mathrm{P}<0.0005)$. Overall, MS responses were higher in January (40-41 g MS/kg DM) than in March (32-34 g $\mathrm{MS} / \mathrm{kg} \mathrm{DM})$ during late lactation. Stage of lactation affects the magnitude of the milk response because of changes in energy partitioning that occur as lactation progresses (Kellaway \& Porta 1993). This factor, combined with a poorer quality pasture $(9.7 \mathrm{MJ} \mathrm{ME} / \mathrm{kg}$ DM), helps explain the lower MS response. The responses from turnips were consistent with the previous two years' results which gave responses of between 42.5 and $50 \mathrm{~g} \mathrm{MS} / \mathrm{kg}$ DM offered (Clark et al. 1997). It could be expected that cows grazing chicory could also achieve these levels.

In January all cows were fed the same amount of each crop to supplement different levels of pasture. Daily MS production increased with increasing pasture allowance; however, the size of the MS response ( $\mathrm{kg}$ MS/kg DM offered) declined. Kellaway \& Porta (1993) comment that it is widely recognised that responses in milk production follow a curve of diminishing returns owing to increasing partitioning of nutrients from milk production to body tissue and that other experiments show as pasture allowances increase, substitution rates increase and marginal responses to supplements decrease.

Our results show the greater benefit from feeding a summer-autumn forage crop to supplement pasture when pasture allowance is low, for instance during a summer drought. This pasture-sparing effect would be particularly beneficial in a dry summer, when pasture is suffering from water and heat stress.

\section{Conclusions}

Chicory is a high quality summer-autumn forage with high yield potential. Milk production responses from chicory are similar to those from turnips, improving milksolids production when supplementing pasture over 
the summer and/or autumn periods. Chicory's advantages as a forage crop are its potential for use in a rotational grazing system and its perennial nature, which enables establishment costs to be spread over a longer period.

\section{ACKNOWLEDGEMENTS}

Many thanks to the staff of No. 1 Dairy (especially Bruce Sugar, Robin Pascoe and Corey Russell) for stock and crop management, Catherine Evans, Elizabeth Grayling, Vicki van Vught, Helen Simons and Karl Baldwin for technical assistance. Special thanks to Rhonda Hooper for statistical analyses and to the Foundation for Research, Science and Technology for funding (contract DRC602).

\section{REFERENCES}

Clark, D.A.; Harris, S.L.; Thom, E.R.; Waugh, C.D.; Copeman, P.J.A.; Napper, A.R. 1997. A comparison of Barkant turnips and Superchow sorghum for summer milk production. Proceedings of the New Zealand Grassland Association 59: 157-161.
Lancashire J.A.; Brock, J.L. 1987. Management of new cultivars for dryland. Proceedings of the New Zealand Grassland Association 44: 61-73.

Li, G.D.; Kemp, P.D.; Hodgson, J. 1997. Herbage production and persistence of Puna chicory (Cichorium intybus L.) under grazing management over 4 years. New Zealand journal of agricultural research 40: 51-56.

Kellaway, R.; Porta, S. 1993. In: Feeding concentrates - supplements for dairy cows. Dairy Research and Development Corporation: p. 119. Agmedia, East Melbourne, Victoria.

Moloney, S.C.; Milne, G.D. 1993. Establishment and management of Grasslands Puna chicory used as a specialist, high quality forage herb. Proceedings of the New Zealand Grassland Association 55: 113118.

National Research Council. 1989. Nutrient requirements of Dairy Cattle. $6^{\text {th }}$ rev. ed. National Academy of Science, Washington, DC.

Rumball, W. 1986. 'Grasslands Puna' chicory (Cichorium intybus L.). New Zealand journal of experimental agriculture 14: 165-171. 